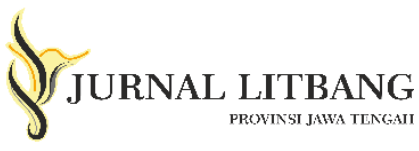

Info Artikel

Diterima : 10 September 2021

Direvisi : 29 Oktober 2021

Disetujui : 1 Desember 2021

Kata kunci:

Kebijakan Pemerintah

Pandemi Covid-19

Perekonomian

Keywords:

Covid-19 Pandemic

Economy

Goverment Policy

Corresponding Author:

Novita Maulida Ikmal

novitamaulidaikmal@uwp.ac.id 081334355142

\section{Kebijakan Pemerintah Indonesia Dalam Penanganan Covid-19}

\author{
Indonesian Government Policies in Handling \\ Covid-19
}

Novita Maulida Ikmal, Machdian Noor

Fakultas Ilmu Sosial dan Ilmu Politik/Program Studi Ilmu Administrasi Negara, Universitas Wijaya Putra

\begin{abstract}
Abstrak
Sepanjang tahun 2020 dunia telah digemparkan dengan munculnya virus baru yang menjangkit dunia saat ini yaitu Coronaviruses (CoV). Nama resmi virus tersebut adalah SARS $\mathrm{CoV} 2$, dan penyakit yang ditimbulkan adalah Coronavirus Disease 2019 (COVID-19). Pandemi COVID-19 juga memberikan dampak cukup besar terhadap investasi yang membuat masyarakat akan memilih untuk sangat hati-hati dalam membeli barang, bahkan untuk melakukan investasi. Pemerintah juga menghimbau agar masyarakat menerapkan social distancing seperti work from home (WFH), dan beribadah dari rumah. Penelitian ini menggunakan teori analisis kebijakan untuk mengungkapkan kebijakan pemerintah dalam menangani perekonomian masyarakat. Penulisan artikel ini merupakan penelitian pustaka (library research) dengan metode kualitatif yang bersifat menjelaskan sesuatu berdasar pada data dan angka yang dinarasikan dalam kalimat. Penelitian ini mengidentifikasi beragam kebijakan yang dilaksanakan oleh pemerintah sebagai upaya menekan penyebaran COVID-19, diantaranya adalah kebijakan preventif, promotif dan jaring pengaman sosial. Selain itu, pemerintah juga berupaya untuk meringankan perekonomian masyarakat akibat adanya pandemi COVID-19 dengan dibentuknya Program Keluarga Harapan, Bantuan Pangan Non-Tunai, Kartu Prakerja, Bantuan Subsidi Listrik. Pemerintah juga menganggarkan dana alokasi dan memberikan keringanan kredit untuk pekerja sektor informal dan pelaku UMKM
\end{abstract}


of the Family Hope Program, Non-Cash Food Assistance, PreEmployment Cards, Electricity Subsidy Assistance. The government also budgets allocation funds and provides credit relief for informal sector workers and UMKM actors.

\section{PENDAHULUAN}

Fenomena yang terjadi di Indonesia sepanjang tahun 2020 yaitu munculnya virus baru yang menjangkit dunia saat ini yang disebut Coronaviruses $(\mathrm{CoV})$. Organisasi internasional bidang kesehatan yaitu World Health Organization menyatakan bahwa Coronaviruses (CoV) dapat menjangkit saluran nafas pada manusia. Virus tersebut memiliki nama ilmiah SARS $\operatorname{CoV} 2$, dan menimbulkan penyakit yang disebut Coronavirus Disease 2019 (COVID-19). COVID-19 dapat memberikan efek mulai dari flu yang sangat ringan sampai yang sangat serius atau bahkan lebih parah dari MERS-CoV dan SARS-CoV (Kirigia \& Muthuri, 2020). Selain itu juga COVID-19 disebut sebagai zoonotic dengan cara penularan melalui manusia/dan hewan.

Terhitung hampir 2 tahun lamanya sejak Pemerintah Indonesia menginformasikan infeksi virus COVID-19 pertamakali pada tanggal 2 Maret 2020. Tidak hanya krisis akan kesehatan masyarakat, pandemi COVID-19 secara nyata juga mengganggu pereknomian masyarakat. Hal ini mulai terlihat dari sejumlah indikator perekonomian, seperti pertumbuhan ekonomi, Survei Kegiatan Dunia Usaha (SKDU), Indeks Manufaktur (PMI), Retail Sales Index, Indeks Keyakinan Konsumen (IKK) dan jasa keuangan (kompas.id, 29 Juli 2021)

Kementerian Keuangan juga menyampaikan bahwa COVID-19 memberikan ancaman kehilangan pendapatan masyarakat. Mereka yang paling terdampak terutama adalah masyarakat yang tidak mampu dan keluarga yang bekerja di sektor informal, kredit macet pada UMKM, sistem korporasi yang terganggu hingga kondisi perbankan yang dapat mengalami persoalan likuiditas, depresiasi rupiah, volatilitas pasar keuangan dan capital flight (Mardiyah dan Nurwati, 2020). Selain itu banyak perusahaan, pabrik, toko dan UMKM yang terpaksa tutup atau bahkan melakukan pengurangan pegawai atau PHK. Pandemi COVID-19 juga memberikan dampak cukup besar terhadap investasi yang membuat masyarakat akan memilih untuk sangat hati-hati dalam membeli barang bahkan untuk melakukan investasi. Investor cenderung untuk tidak berinvestasi dikarenakan berubahnya asumsi pasar dan tidak jelasnya supply chain (Pepinsky \& Wihardja, 2011).

Honoatubun (2020), juga mengemukakan bahwa akibat mewabahnya virus corona pasar ditutup dan pedagang menjadi tidak bisa berjualan. Hal ini mengakibatkan pedagang tidak mempunyai penghasilan tetap dan sulit untuk memenuhi kebutuhan hidupnya. Selain itu dampak yang dialami sektor ekonomi Indonesia saat ini adalah:

1. Lebih dari 1,5 juta pekerja yang dirumahkan dan kena PHK. Dari jumlah ini, 90 persen dirumahkan dan 10 persen kena-PHK. Sebanyak 1,24 juta orang adalah pekerja formal dan 265 ribu pekerja informal.

2. dampak kedua, PMI Manufacturing Indonesia mengalami kontraksi atau turun hingga 45,3 pada Maret 2020. Padahal dari angka terakhir yaitu Agustus 2019, PMI Manufacturing masih berada di angka 49. Adapun PMI Manufacturing ini menunjukkan kinerja industri pengolahan, baik dari sisi produksi, permintaan baru, hingga ketenagakerjaan.

3. Impor pada triwulan I 2020 turun 3,7 persen year-to-date (ytd).

4. Inflasi/ peningkatan harga secara umum dan terus menerus Maret 2020 mencapai 2,96 persen year-on-year (yoy). Inflasi ini disumbangkan oleh harga emas perhiasan dan beberapa komoditas pangan.

5. Kelima, 12.703 penerbangan di 15 bandara dibatalkan sepanjang Januari- 
Maret 2020. Rinciannya yaitu 11.680 untuk penerbangan domestik dan 1.023 untuk penerbangan internasional.

6. kunjungan turis turun hingga 6.800 per hari, khususnya turis dari China.

7. Ketujuh, angka kehilangan pendapatan di sektor layanan udara mencapai Rp 207 miliar. Sekitar Rp 4,8 di antaranya disumbang dari penerbangan dari dan ke China.

8. penurunan okupansi/penempatan pada 6 ribu hotel turun hingga 50 persen. Selain itu, kata Sri, Menteri Pariwisata dan Ekonomi Kreatif Wishnutama juga memperkirakan potensi kehilangan devisa pariwisata bisa mencapai setengah dari tahun lalu.

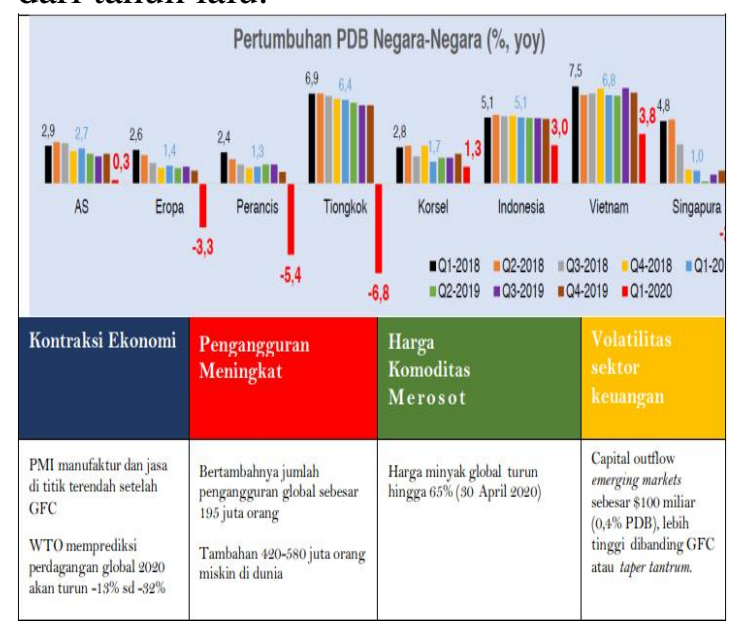

Sumber: Kementerian Keuangan Republik Indonesia (2020), Program Pemulihan

Ekonomi Nasional (PEN), April 2020

Gambar 1. Dampak Global Pandemi COVID-19

Gambar diatas menunjukkan bahwa pandemi COVID-19 diperkirakan juga akan mengurangi arus perdagangan dan investasi global hingga $30 \%$, serta menambah volatilitas pasar keuangan dunia hingga $215 \%$. Berkurang drastisnya berbagai aktivitas perekonomian global pada gilirannya diperkirakan akan mengakibatkan tidak kurang 195 juta orang akan mengalami kehilangan pekerjaan dan antara 420 sampai 580 juta orang jatuh pada jurang kemiskinan.

Data terakhir Badan Pusat Statistik (BPS) pada Agustus 2019 juga menunjukkan tingkat penganguran terbuka mencapai 7,05 juta orang atau 5,28\% dari jumlah angkatan kerja. Center of Reform on Economics (CORE) Indonesia memperkirakan jumlah pengangguran terbuka pada kuartal kedua 2020 akan bertambah 4.25 juta orang (Sihaloho, 2020). Pandemi COVID-19 juga memberikan dampak cukup besar terhadap investasi yang membuat masyarakat akan memilih untuk sangat hati-hati dalam membeli barang bahkan untuk melakukan investasi. Investor cenderung untuk tidak berinvestasi dikarenakan berubahnya asumsi pasar dan tidak jelasnya supply chain (Pepinsky \& Wihardja, 2011).

Untuk itu diperlukan adanya pernyataan kebaruan dari penelitian yang dilakukan yang diperkuat dengan kajian literatur dari penelitian terdahulu. Sumber state of the art dianjurkan dari sumber primer yaitu sumber referensi jurnal yang relevan dan publikasi terkini baik jurnal internasional maupun jurnal nasional.

Artikel ini berusaha untuk menjelaskan apakah kebijakan pemerintah sudah tepat atau justru kurang tepat dalam menangani permasalahan perekonomian. Karena itu, tulisan ini mengkaji tentang kebijakankebijakan pemerintah dalam menanganani Covid-19 dalam bidang perekonomian.

\section{METODE PENELITIAN}

Secara kategorial bahwa permasalahan COVID-19 meliputi terdampaknya pada penurunan pendapatan masyarakat dan kesulitan dalam hal perekonomian. Sedangkan kebijakan pemerintah dalam penanganan COVID-19 sendiri salah satunya adalah adanya program Jaring Pengaman Sosial (JPS), serta adanya kebijakan preventif dan promotif. Untuk membahas masing-masing masalah tersebut, metode yang digunakan dalam penelitian ini adalah penelitian kualitatif, yang bersifat studi pustaka (library research) yang menggunakan buku-buku dan literaturliteratur lainnya sebagai bahan utama yang berkaitan dengan obyek penelitian atau permulaan data yang bersifat kepustakaan. Adapun beberapa sumber yang digunakan 
antara lain: buku-buku teks, jurnal ilmiah, referensi statistik, hasil-hasil penelitian dalam bentuk skripsi, tesis, desertasi, internet serta sumber-sumber lainnya yang relevan (Sanusi, 2016: 32).

Teknik yang digunakan dalam pengumpulan data adalah pengumpulan data literatur yaitu bahan-bahan yang koheren dengan objek-objek pembahasan yang dimaksud (Suharsimi, 1990:24). Data yang ada dalam kepustakaan tersebut dikumpulkan dan diolah dengan cara: editing, organizing, penemuan hasil penelitian. Analisis data dalam penelitian pustaka ini adalah analisis isi (content analysis) yaitu penelitian yang bersifat pembahasan mendalam terhadap isi suatu informasi tertulis atau tercetak. Analisis isi adalah suatu teknik penelitian untuk membuat infrensi-infrensi yang dapat ditiru dan sahih data dengan memperhatikan konteksnya. (Krippendrof, 1993: 15).

Data-data yang digunakan oleh peneliti merupakan data banyaknya jumlah kasus COVID-19 dari sumber yang dianggap kredibel, juga disertai kebijakan-kebijakan pemerintah untuk mengatasi perekonomian masyarakat selama pandemi berlangsung. Penelitian ini menggunakan model analisis Triangulasi (Rahardjo, 2010), peneliti menggabungkan data yang sejenis dan membuat simpulan dari setiap data tersebut menjadi sebuah simpulan yang akhirnya dapat dijadikan narasi yang dapat memudahkan pembaca dalam memahami setiap tujuan-tujuan yang telah penulis tetapkan. Proses ini dapat dilihat pada Gambar 2.

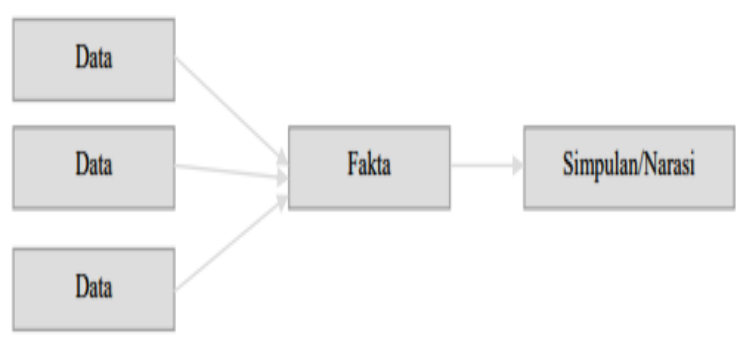

Gambar 2. Proses Triangulasi

\section{HASIL DAN PEMBAHASAN}

Sebagai konsekensi dari persoalan COVID-19 dan cara bagaimana pemerintah merespon dengan sejumlah kebijakan, maka hasil kajiannya adalah sebagai berikut: Pada tanggal 2 Maret 2020, Indonesia untuk pertama kalinya mengkonfirmasi kasus COVID-10 (Tim detik.com, 2021). Hingga per tanggal 9 Agustus 2021, tercatat 31.991 kasus COVID-19 yang telah menyebar di 34 provinsi di Indonesia.

Kondisi pandemi COVID-19 yang terjadi saat ini membawa dampak yang cukup serius pada tatanan perekonomian di Indonesia, hampir $50 \%$ diantaranya mengalami kesulitan keuangan (Webinar Semeru Research Institute, 4 Maret 2021). Keterbatasan lapangan pekerjaan karena kegiatan bisnis yang menurun akibat adanya berbagai kebijakan salah satunya yaitu adanya kebijakan Pembatasan Sosial Berskala Besar (PSBB) pada tahun 2020 silam.

Akses untuk mendapatkan layanan dasar sosial juga semakin sulit di saat pandemi, oleh karena itu masyarakat kesulitan untuk mendapatkan layanan kesehatan, makanan dan pendidikan bagi anak. Beberapa waktu akhir ini, tingkat kasus COVID-19 mengalami peningkatan di berbagai daerah. Laju peningkatan kasus COVID-19 hingga 2021 tercatat pada gambar dibawah ini:

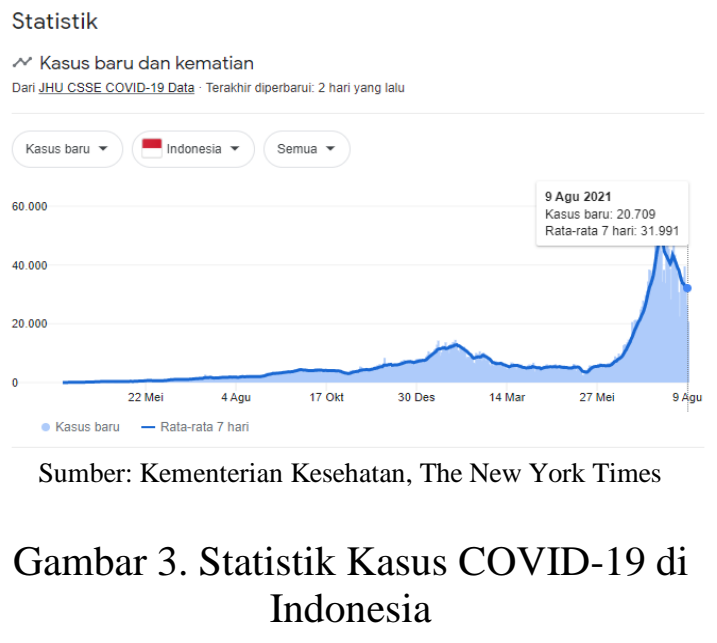


Upaya pemerintah untuk menekan angka penyebaran COVID-19 masih terus dilakukan. Kronologi kebijakan lain yang diterapkan oleh pemerintah selama masa pandemi COVID-19 terhitung ketika Indonesia mengkonfirmasi bahwa wabah COVID-19 masuk ke Indonesia yaitu (Kompas.id):

02 April 2020, Gubernur DKI Jakarta Anies Baswedan mengirimkan surat ke Menteri Kesehatan untuk persetujuan PSBB (Pembatasan Sosial Berskala Besar) di Jabodetabek. Berdasarkan data per tanggal 2 April 2020, sebanyak 885 kasus pasien terkonfirmasi positif COVID-19 di Jakarta.

07 April 2020, Terbit peraturan Menkes tentang Pedoman PSBB dalam rangka percepatan penanganan COVID-19 yang harus diterapkan di berbagai daerah.

10 April - 23 April 2020, Penerapan PSBB di Jakarta ditetapkan mulai 10 April hingga 23 April 2020. Selain Jakarta, beberapa daerah yang juga menerapkan PSBB yaitu Provinsi Jawa Barat dan Banten juga mengajukan PSBB kepada Menkes. Pembatasan sosial berskala besar juga meliputi peliburan sekolah dan tempat kerja, pembatasan kegiatan keagamaan, pembatasan kegiatan di tempat umum, pembatasan kegiatan sosial budaya, pembatsan moda transportasi.

24 April - 4 Juni 2020, PSBB yang semula hanya 14 hari diperpanjang hingga 4 Juni 2020 karena persebaran COVID-19 yang belum mereda. Salah satu dampak PSBB bagi pengguna jalan adalah adanya check point di beberapa jalan di kota besar.

05 Juni - 10 September, Pada periode ini muncul masa transisi bagi masyarakat untuk berlatih pada kehidupan New Normal. Hal ini ditandai dengan pelonggaran aktivitas ekonomi di tempat usaha dan gedung, rumah ibadah, serta perkantoran dengan syarat mematuhi protokol kesehatan. Penetapan PSBB transisi ini dilaksanakan karena tingkat penularan COVID-19 per 3 Juni 2020 berada dibawah 0,99 yang artinya dapat dikendalikan. Pada PSBB periode ini juga melonggrakan izin buka untuk tempat umum seperti taman rekreasi. Beberapa ketentuan yang masih berlaku yaitu:

1. Perilaku hidup bersih dan sehat, menggunakan masker dan menjaga jarak

2. Perkantoran dibuka dengan maksimal $50 \%$ WFO

3. Tempat ibadah mulai dibuka dengan kapasitas Jemaah maksimal 50\%

4. UMKM, taman, dan pantai juga sudah dibuka dengan batas pengunjung 50\% dan dilarang untuk berkerumun

5. Kendaran pribadi dan transportasi umum kapasitas juga dibatasi dan tetap menjaga jarak

14 September - 11 Oktober 2020, Pemprov DKI Jakarta kembali menerapkan PSBB Ketat setelah mempertimbangkan tiga hal yakni angka kematian, jumlah pasien di ruang isolasi dan ICU, serta ruang perawatan intensif di rumah sakit. Beberapa sektor usaha yang diperbolehkan untuk beroperasi adalah sektor kesehatan, bahan pangan, makanan dan minuman akan tetapi pengunjung hanya bisa memesan untuk dibawa pulang. Kemudian sektor yang lain yaitu seperti sektor energi, komunikasi dan teknologi informasi, keuangan, logistik, perhotelan, dan konstruksi.

12 Oktober - 11 Januari 2021, Pada periode ini kembali ditetapkannya PSBB transisi dengan acuan perlambatan kenaikan kasus penularan COVID-19. Kasus positif COVID-19 dan kasus aktif harian terpantau stabil. Dalam kembalinya PSBB transisi ini, sejumlah pembatasan dilonggarkan kembali, diantaranya makan di restoran diizinkan dengan protokol kesehatan ketat, kemudian akan diikuti pembelajaran tatap muka.

11 Januari - 25 Januari, Di Jakarta pada periode ini PSBB diatur dalam Keputusan Gubernur DKI Nomor 19 Tahun 2021 tentang pemberlakuan, jangka waktu, dan pembatasan aktivasi luar rumah PSBB.

26 Januari - 8 Februari 2021, Pemerintah menerapkan Pemberlakuan Pembatasan Kegiatan Masayarakat (PPKM) secara serentak untuk wilayah Jawa dan Bali. Di semua daerah yang harus menjalankan PPKM ketentuan yang diterapkan adalah 
sistem kerja WFH (Work From Home) bagi $75 \%$ pekerja, pusat belanja dan cafe hanya beroperasi sampai pukul 19.00. Terdapat sanksi bagi masyarakat yang tidak menggunakan masker di tempat umum dengan membersihkan fasilitas umum atau membayar denda Rp 250.000.

9 Februari - 28 Juni, PPKM berskala mikro diterapkan dengan mencakup sampai level unit terkecil yaitu tingkat desa/kelurahan dengan membentuk pos komando penanganan COVID-19. Ketentuan tersebut mencakup jam operasional mall dan pusat perbelanjaan lain beroperasi sampai pukul 21.00, fasilitas umum masih ditutup, dan kegiatan sosial budaya dihentikan.

3 Juli - 25 Juli 2021, Diberlakukan PPKM darurat di Jawa dan Bali oleh Presiden Joko Widodo. Cakupan area PPKM darurat meliputi 48 kabupaten/kota. PPKM darurat meliputi pembatasan ketat aktivitas masyarakat seperti penyekatan di pintu masuk antar kota dan antar provinsi. Beberapa kebijakan PPKM darurat JawaBali:

1. Aktivitas bekerja: Sektor non esensial dan kritikal $100 \%$ WFH sedangkan sektor esensial maksimal 50\% staf WFO

2. Aktivitas perdagangan: Supermarket, pasar tradisional dibatasi jam operasional sampai pukul 20.00 dengan kapasitas pengunjung $50 \%$, apotek beroperasi 24 jam, pusat perbelanjaan seperti mall ditutup, tempat makan hanya menyediakan layanan antar.

3. Aktivitas sosial: Tempat ibadah ditutup sementara, kegiatan seni budaya dan olahraga dihentikan sementara, fasilitas area publik ditutup sementara, resepsi pernikahan dihadiri maksimal 30 orang dan tidak diperbolehkan berkerumun atau makan di tempat.

4. Mobilitas masyarakat: transportasi umum diberlakukan dengan kapasitas maksimal $70 \%$, pelaku perjalanan domestic yang menggunakan transportasi jarak jauh harus menunjukkan kartu vaksin (minimal dosisi 1) dan PCR dan/atau antigen.
26 Juli - 2 Agustus, Presiden Jokowi memperpanjang PPKM level 3 dan 4 hingga 2 Agustus 2021. Keputusan ini dikeluarkan dengan mempertimbangkan tingginya angka kasus COVID-19 di tingkat desa. Menindaklanjuti keputusan presiden tersebut, Mendagri menerbitkan tiga instruksi yaitu Inmendagri Nomor 24 Tahun 2021 tentang PPKM Level 4 dan Level 3 COVID-19 di Wilayah Jawa dan Bali, Inmendagri Nomor 25 Tahun 2021 tentang PPKM Level 4 COVID-19 di Wilayah Sumatera, Kalimantan, Sulawesi, Nusa Tenggara, Maluku, dan Papua, serta Inmendagri Nomor 26 Tahun 2021 tentang PPKM level 3, level 2 dan level 1 serta mengoptimalkan posko penanganan COVID-19 di tingkat desa dan kelurahan. Perbedaan PPKM level 1 hingga 4 yang diterapkan pemerintah yaitu:

1. PPKM Level 1-2:

a. $100 \%$ kegiatan Pendidikan dilaksanakan secara daring.

b. $25 \%$ pekerja kantor WFH

c. Sektor non esensial beroperasi $100 \%$

d. Kegiatan makan atau minum di warung atau pedagang kaki lima diizinkan dengan kapasitas $25 \%$

e. Pusat perbelanjaan diperbolehkan beroperasi maksimal pukul 17.00

f. Resepsi pernikahan diperbolehkan dengan pengunjung berkapasitas $25 \%$ dan tidak berkerumun.

2. PPKM Level 3:

a. Kegiatan makan dan minum di warung atau pedagang kaki lima dibatasi dengan pengunjung $25 \%$ dengan maksimal buka pukul 20.00

b. Pusat perbelanjaan dengan kapasitas maksimal $25 \%$ dengan jam operasional pukul 17.00

c. Kegiatan resepsi pernikahan hanya dihadiri oleh keluarga atau 20 orang tamu dan tidak berkerumun

d. Ibadah dilaksanakan dengan maksimal $25 \%$ atau 20 orang Jemaah dengan menggunakan protokol ketat.

\section{PPKM Level 4:}


Jurnal Litbang Provinsi Jawa Tengah, Vol. 19, No. 2, Desember 2021, hal. 155 - 166
a. Pemerintah memperbolehkan makan di warung atau café dengan batas hanya sampai maksimal 20 menit
b. Selain pedagang makanan diizinkan buka sampai pukul 20.00
c. Pasar rakyat kebutuhan pokok dapat beroperasi $100 \%$ sedangkan pasar yang non kebutuhan hanya dapat berkapasitas maksimal $50 \%$ dengan jam buka sampai pukul 15.00
e. Pembelian dapat diakses melalui delivery atau take away
f. Kegiatan belajar mengajar dilakukan secara daring
g. Tidak mengadakan kegiatan peribadatan atau keagamaan berjamaah
h. Angkutan umum hanya boleh berkapasitas $50 \%$
i. Pemerintah melarang adanya kegiatan resepsi untuk sementara waktu
d. Pusat perbelanjaan atau mall ditutup sementara

Tabel 1. Kebijakan Pembatasan Sosial

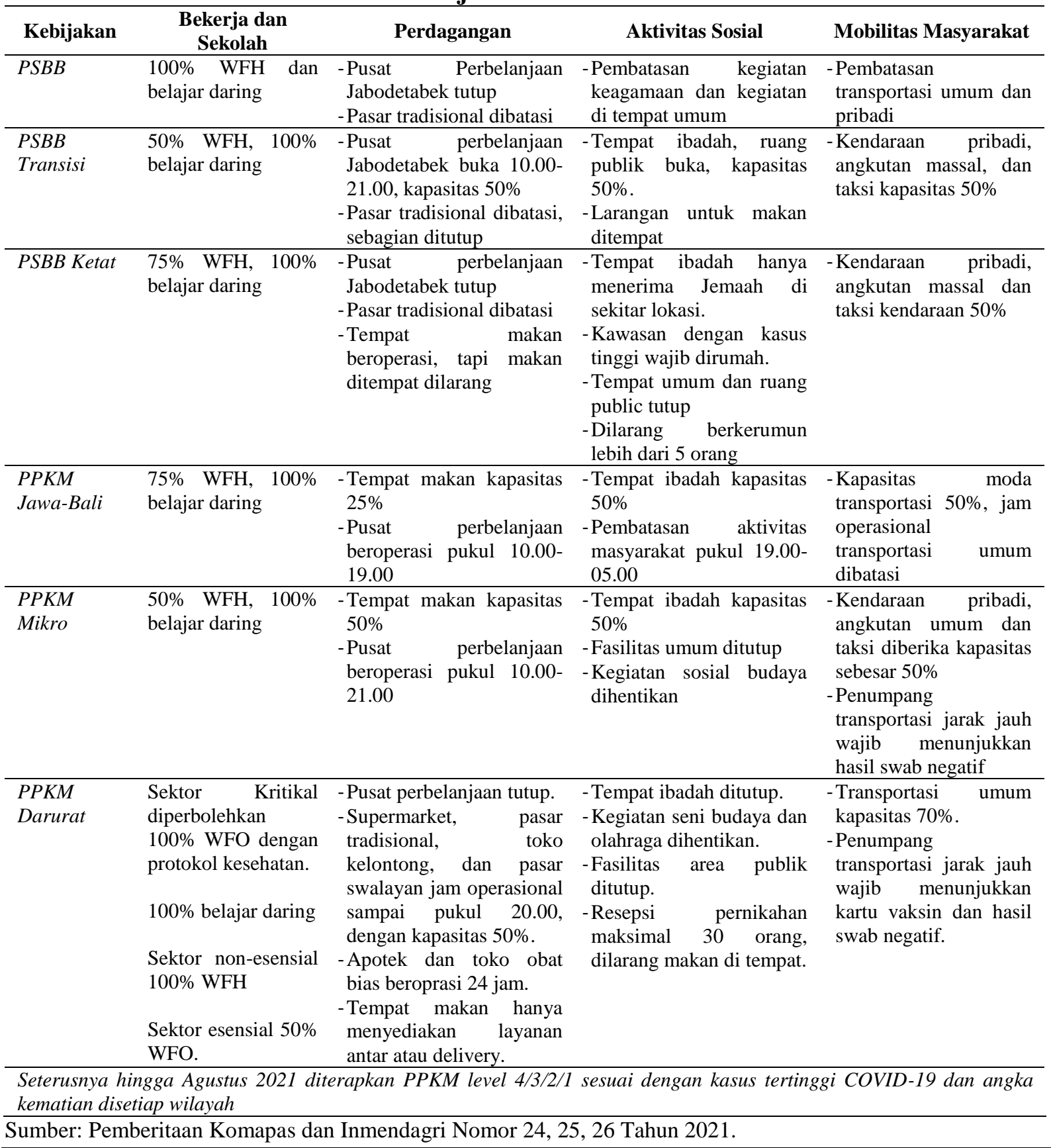

Novita Maulida Ikmal, Machdian Noor

Kebijakan Pemerintah Indonesia Dalam Penanganan Covid-19 
Selain itu juga di tahun 2020 pemerintah merespon dampak COVID-19 dengan mengeluarkan berbagai regulasi dan kebijakan diantaranya adalah Peraturan Pemerintah Pengganti Undang-undang (Perppu) Nomor 1 Tahun 2020 tentang Kebijakan Keuangan Negara dan Stabilitas Sistem Keuangan untuk Penanganan Pandemi COVID-19 dalam Rangka Menghadapi Ancaman yang membahayakan Perekoniman Nasional atau stabilitas Sistem Keuangan. Perppu tersebut kemudian disahkan menjadi Undang-Undang Nomor 2 Tahun 2020 pada 31 Maret 2020. Kebijakan keuangan negara tersebut meliputi kebijakan pendapatan negara termasuk kebijakan di perpajakan, kebijakan belanja negara termasuk kebijakan di bidang keuangan daerah, dan kebijakan pembiayaan. Sedangkan, kebijakan stabilitas sistem keuangan meliputi kebijakan untuk penanganan permasalahan lembaga keuangan yang membahayakan perekonomian nasional atau stabilitas sistem keuangan.

Sebagai turunan dari Perppu di atas, pemerintah juga menerbitkan Peraturan Presiden Nomor 54 Tahun 2020 tentang Perubahan Postur dan Rincian Anggaran Pendapatan dan Belanja Negara Tahun Anggaran 2020 pada tanggal 4 April 2020. Selanjutnya Perpres tersebut diubah dengan Peraturan Presiden Nomor 72 Tahun 2020 tentang Perubahan Postur dan Rincian APBN 2020 yang telah ditetapkan pada 24 Juni 2020. Akibat adanya penurunan kinerja ekonomi, pemerintah mulai melakukan upaya pemulihan ekonomi nasional melalui Program Pemulihan Ekonomi Nasional (PEN). Tujuan dari program tersebut adalah untuk mempertahankan dan meningkatkan kemampuan ekonomi para pelaku usaha dari sektor riil dan sektor keuangan dalam menjalankan usahanya selama pandemi COVID-19.

Program Pemulihan Ekonomi Nasional (PEN) tertuang dalam Peraturan Pemerintah Nomor 23 Tahun 2020 ditetapkan pada tanggal 9 Mei 2020. Program Pemulihan Ekonomi Nasional (PEN) dilaksanakan melalui empat modalitas dan belanja negara yaitu: 1) penyertaan modal negara (PMN), 2) penempatan dana, 3) investasi pemerintah, dan 4) kegiatan penjaminan dengan skema yang ditetapkan oleh pemerintah. Setelah itu pemerintah menerbitkan Peraturan Presiden Nomor 82 Tahun 2020 yang dikeluarkan 27 Juli 2020. Kebijakan tersebut membahas tentang Komite Penanganan COVID-19 dan Pemulihan Ekonomi Nasional. Komite tersebut terdiri atas Komite Kebijakan, Satuan Tugas Penanganan Covid-19, dan Satuan Tugas Pemulihan dan Transformasi Ekonomi Nasional.

Secara umum, tren positif realisasi program PEN didukung oleh berbagai upaya akselerasi, diantaranya percepatan belanja penanganan COVID-19, percepatan program PEN yang lain diantaranya adalah insentif usaha, DAK Fisik, Dana Insentif Daerah (DID) Pemulihan, dan Pra Kerja, serta dengan mengoptimalkan program-program baru yang dapat langsung direalisasikan yaitu program Bantuan Produktif UMKM (BPUM) dan Subsidi Gaji/Upah.

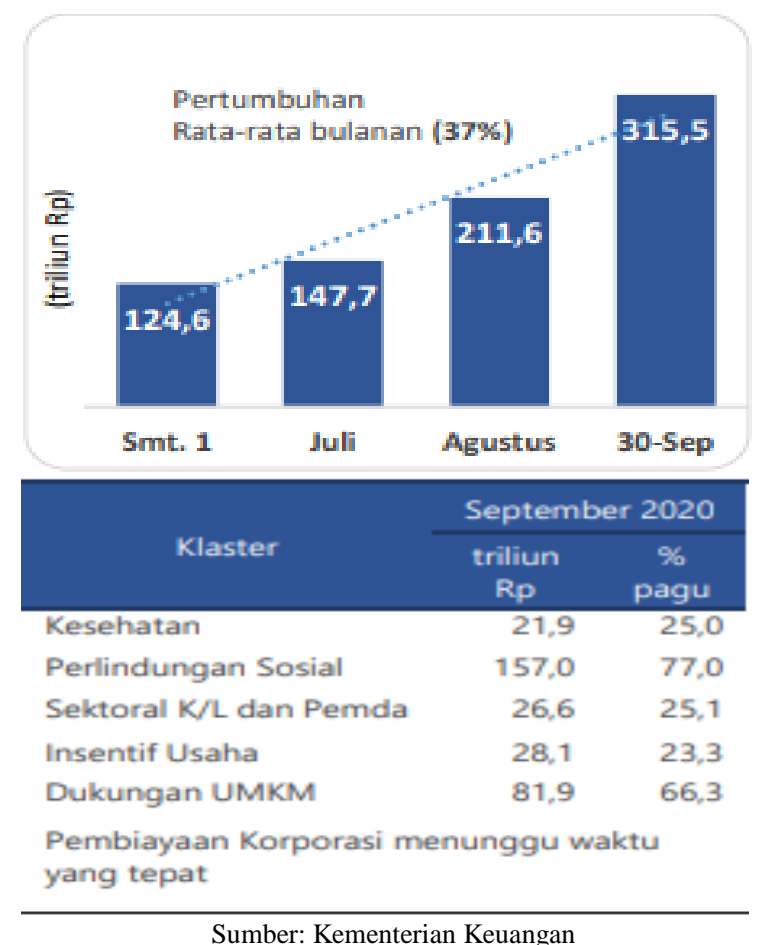

Gambar 4. Perkembangan dan Rincian Realisasi Anggaran PEN 
Pada Tahun 2021, anggaran yang telah dikeluarkan pemerintah untuk penanganan COVID-19 dan Pemulihan Ekonomi Nasional (PEN) sebesar Rp 695,20 triliun yang dialokasikan untuk 6 sektor di Indonesia. Total yang direalisasikan hingga minggu pertama Agustus 2021 adalah Rp 151,125 triliun (kemenkeu.go.id, 10 Juni 2021). Selanjutnya, untuk memenuhi aktivitas sosial dan ekonomi untuk masyarakat yang pendapatnnya terdampak pandemi pemerintah telah mempersiapkan jaring pengamanan sosial. Realisasi untuk perlindungan sosial sebesar Rp 85,3 triliun dari pagu Rp 203,91 triliun. Anggaran yang sudah direalisasikan untuk Program Keluarga Harapan (PKH) sebesar Rp 26,6 triliun, Bantuan Langsung Tunai (BLT) dana desa sebesar Rp 8,3 triliun, kartu sembako Rp 25,5 triliun, program prakerja $\mathrm{Rp} 2,4$ triliun, bantuan tunai non-jabodetabek $\mathrm{Rp} \quad 16,5$ triliun dan diskon listrik $\mathrm{Rp} 3,1$ triliun (nasional.kontan.co.id, 6 Juli 2021).

Tabel 2. Potret Singkat Perekonomian dan Anggaran PEN

\begin{tabular}{|c|c|c|}
\hline Potret Ekonomi 2020 & $\begin{array}{l}\text { Anggaran PEN 2020: } \\
\text { Rp 695,20 triliun }\end{array}$ & $\begin{array}{l}\text { Anggaran PEN 2021: } \\
\text { Rp 553,09 triliun }\end{array}$ \\
\hline $\begin{array}{l}\text { - } \text { Pertumbuhan } \\
\text { Kuartal II: minus 5,32\%, } \\
\text { Kuartal III: minus } 3,49 \\
\text { (resesi) } \\
\text { - Survei Kegiatan Usaha } \\
\text { (SKDU): minus, ada } \\
\text { perbaikan di akhir tahun } \\
\text { - PMI Manufaktur di level } \\
\text { ekspansi (51,3) per Desember } \\
\text { - Retail Sales Index: belum } \\
\text { pulih (November menurun } \\
\text { dibandingkan Oktober) } \\
\text { - Indeks Keyakinan Konsumen: } \\
\text { Mendekati optimis pada akhir } \\
\text { tahun (96,5) } \\
\text { - Defisit APBN 2020 naik } \\
\text { menjadi 6,34\% PDB }\end{array}$ & $\begin{array}{l}\text { - Kesehatan: Rp 86,64 } \\
\text { triliun } \\
\text { - Perlindungan sosial: Rp } \\
\text { 242,15 triliun } \\
\text { - Sektoral K/L dan Pemda: } \\
\text { Rp 68,78 triliun } \\
\text { - UMKM: Rp 128,21 triliun } \\
\text { - Pembiayaan Korporasi: Rp } \\
48,85 \text { triliun } \\
\text { - Insentif usaha: Rp 120,61 } \\
\text { triliun } \\
\text { - Realisasi PEN 2020: Rp } \\
\text { 579,78 triliun }(83,4 \%)\end{array}$ & $\begin{array}{l}\text { - Kesehatan Rp } 104,7 \text { triliun } \\
\text { - Perlindungan sosial Rp } \\
150,9 \text { triliun } \\
\text { - Program prioritas Rp } \\
141,36 \text { triliun } \\
\text { - Dukungan UMKM dan } \\
\text { pembiayaan korporasi Rp } \\
150,6 \text { triliun }\end{array}$ \\
\hline
\end{tabular}

Terdapat tiga kebijakan yang dilakukan pemerintah yaitu peningkatan konsumsi dalam negeri, peningkatan aktivitas dunia usaha, serta menjaga stabilitas ekonomi dan ekspansi moneter. Di sektor dunia usaha, pemerintah berusaha menggerakkan perekonomian melalui pemberian insentif kepada UMKM dan korporasi. Untuk UMKM pemerintah memberikan penundaan angsuran dan subsidi bunga kredit perbankan, subsidi bunga melalui Kredit Usaha Rakyat (KUR) dan Ultra Mikro, penjaminan modal kerja sampai Rp 10 miliar dan pemberian insentif pajak, misalnya Pajak Penghasilan (PPh Pasal 21) ditanggung pemerintah (kompas.id, 13/05/21).

\section{Pembahasan \\ Kebijakan Pemerintah}

Di Indonesia, pemerintah telah melakukan berbagai strategi dalam menangani penambahan kasus positif COVID-19. Adapun strategi yang diberlakukan oleh Pemerintah Indonesia terbagi menjadi empat hal yang secara konsisten dilakukan, yaitu: 1) kewajiban 
memakai masker saat berada di ruang publik atau di luar rumah, 2) penelusuran kontak (tracing) dari kasus positif yang dirawat dengan menggunakan rapid test, 3) edukasi dan penyiapan isolasi secara mandiri pada sebagian hasil tracing yang menunjukan hasil tes positif dari rapid tes atau negatif dengan gejala untuk melakukan isolasi mandiri, 4) strategi selajutnya adalah isolasi rumah sakit yang dilakukan ketika saat isolasi mandiri tidak dapat dijalankan. Sedangkan physical distancing merupakan strategi dasar untuk mengatasi pandemi COVID-19. Selain itu, dalam bidang ekonomi pemerintah juga memberlakukan Jaring Pengaman Sosial untuk membantu masyarakat dalam melewati masa pandemi COVID-19.

\section{Strategi Preventif dan Promotif}

Pemerintah pada dasarnya secara proaktif berupaya untuk mencegah dan meningkatkan kesadaran masyarakat akan bahaya virus COVID-19 di Indonesia. Salah satu upaya pemerintah secara aktif untuk mencegah penyebaran virus adalah dengan diberlakukakannya berbagai kebijakan dan peraturan dalam beraktivitas di luar rumah. Selain itu juga pemerintah berupaya untuk meningkatkan imunitas masyarakat baik dari obat-obatan dan/atau vaksinasi. Hal ini dilakukan sebagai upaya pencegahan virus COVID-19 di berbagai klaster.

Selain itu juga melalui berbagai iklan baik di TV Nasional maupun di papan banner, pemerintah berupaya untuk menghimbau masyarakat menerapkan pola hidup bersih dengan mencuci tangan, memakai masker, jaga jarak dan menghindari kegiatan yang menimbulkan kerumunan orang. Anjuran yang disarankan oleh Menteri Kesehatan RI bahwa jarak aman untuk memenuhi kaidah physical distancing adalah minimal satu meter, hal ini dilakukan agar tidak terjadi penyebaran COVID-19 melalui udara. Dalam upaya mewujudkan strategi preventif Presiden Jokowi mendirikan gugus tugas percepatan penanganan COVID-19 yang difungsikan sebagai juru teknis penanganan pandemi COVID-19. Adanya penerapan Pembatasan Sosial Berskala Besar (PSBB) melalui Permenkes 9 tahun 2020 untuk mencegah penyebaran virus COVID19 yang lebih luas. Hal ini juga sebagai menekan laju angka kematian masyarakat akibat terpapar virus COVID-19.

Pemerintah juga menghimabu kepada individu yang mengkonfirmasi bahwa terpapar COVID-19 juga harus ditelusuri pernah kontak dengan siapa saja dengan ditunjukkan hasil negatif rapid tes, jika hasilnya reaktif maka harus dilakukan tes PCR. Menteri Kesehatan RI juga menginfokan bahwa bagi kelompok pasien COVID-19 yang beresiko tinggi, direkomendasikan agar isolasi di fasilitas kesehatan dalam jangka waktu 14 hari sesuai dengan kondisi pasien. Sedangkan pada kelompok COVID-19 yang beresiko rendah dihimbau untuk melakukan isolasi mandiri dengan memperhatikan prosedur kesehatan.

\section{Strategi Jaring Pengaman Sosial}

Program JPS selama pandemi COVID-

19 adalah program yang dirancang untuk membantu rakyat miskin yang terkena dampak akibat pandemi COVID-19 dan dilaksanakan melalui tahapan penyelamatan dan pemulihan menuju pada kondisi normal. Konsep JPS diperkenalkan oleh kelompok kapitalis pada saat peralihan ekonomi di negara-negara Eropa Timur tahun 1900an. Saat itu terjadi transisi ekonomi dari sistem ekonomi sosialis ke sistem ekonomi pasar. Transisi sistem ekonomi ini mengakibatkan kelompok masyarakat miskin yang selama sistem ekonomi sosialis mendapatkan jatah pangan gratis dari pemerintah menjadi tidak lagi mendapatkan jatah pangan gratis (Nasrah, 2020:125). Program ini bertujuan untuk meringankan beban bagi keluarga miskin dan rentan terdampak COVID-19.

Berdasarkan konferensi pers yang dilakukan oleh Presiden Jokowi per tanggal 31 Maret 2020, telah diumumkan skema Jaring Pengaman Sosial. Adapun rincian skema bantuannya yaitu (Maftuchan, 2020):

1. Program Keluarga Harapan (PKH) untuk 10 juta keluarga penerima manfaat selama 
12 bulan. Seperti untuk ibu hamil $\mathrm{Rp}$ 3.000.000 per tahun, keluarga dengan anak usia dini sebesar Rp 3.000.000 per tahun, keluarga dengan disabilitas $\mathrm{Rp}$ 2.400.000 per tahun. Kebijakan ini telah efektif sejak bulan April 2020 dengan anggaran yang dialokasikan sebesar 37,4 Triliun.

2. Bantuan Pangan Non-Tunai (BPNT). Pemerintah meningkatkan juga penerima bantuan BPNT dari 15,2 juta menjadi 20 juta dengan diikuti naiknya persentase besaran bantuan $30 \%$ dari Rp 150.000 per penerima menjadi Rp 200.000 per penerima.

3. Adanya Kartu Prakerja berupa insentif sebesar Rp 600.000 per 4 bulan

4. Bantuan Subsidi Listrik. Pemerintah memberi subsidi penuh terhadap pelanggan listrik bertegangan $450 \mathrm{VA}$, selain itu pemerintah juga memberikan subsidi bagi pengguna listrik bertegangan 900 VA selama 3 bulan

5. Alokasi cadangan anggran, dana sebesar Rp 25 Triliun akan digunakan kebutuhan pokok, operasi pasar dan logistik

6. Keringanan kredit dibawah 10 miliar untuk pekerja sektor informal dan pelaku UMKM

7. BLT Dana Desa untuk 11 juta penerima manfaat selama 3 bulan diluar penerima PKH, Kartu Sembako, Bansos Tunai dan Prakerja.

\section{SIMPULAN}

Pandemi COVID-19 telah mengubah laju perekonomian, hal ini disebabkan karena adanya berbagai regulasi dan kebijakan yang menyempitkan sektor ekonomi untuk berkembang. Sejak 2020 akibat adanya pandemi COVID-19 perekonomian negara mengalami penurunan, selain itu juga angka pengangguran dan kemiskinan semakin meningkat. Berbagai upaya pemerintah untuk mengembalikan perekonomian salah satunya dengan Program Pemulihan Ekonomi Nasional (PEN) yang bertujuan untuk mempertahankan dan meningkatkan kemampuan ekonomi para pelaku usaha dari sektor riil dan sektor keuangan dalam menjalankan usahanya selama pandemi COVID-19.

Pemerintah memberikan anggaran sebesar Rp 695,20 triliun di tahun 2020 dan sebesar Rp 553,09 triliun di tahun 2021. Selain itu untuk menangani krisis tersebut, pemerintah telah menerapkan programprogram jaring pengaman sosial (JPS). Program tersebut terdiri dari bantuan sosial, percepatan pelaksanaan Kartu Prakerja dan pemotongan tagihan listrik.

\section{SARAN}

Pemerintah perlu menyusun mekanisme yang tepat untuk pendataan sasaran dan penyaluran bantuan sosial, menyesuaikan pelatihan kartu prakerja dengan kebutuhan prioritas, memperluas cakupan sasaran dan mengubah skema bantuan lsitrik, serta menjamin keberlangsungan usaha mikro dan kecil (UMK) agar mereka terhindar dari kebangkrutan.

\section{DAFTAR PUSTAKA}

Rahardjo, M. 2010. Triangulasi dalam penelitian kualitatif. Sekolah Pascasarjana Universitas Islam Negeri Maulana Malik Ibrahim: Malang.

Nasrah, Hidayati dkk. 2020. Implementasi Program Jaring Pengaman Sosial Pada Masa Pandemi COVID-19 di Pekanbaru, Jurnal El-Riyasah, Vol 11, No 2 Tahun 2020

Maftuchan, A. 2020. Program Tunai di Era COVID-19: Bantuan Tunai Korona atau Jaminan Penghasilan Semesta, Program Tunai Di Era COVID-19: Bantuan Tunai Korona Atau Jaminan Penghasilan Semesta

Honoatubun, S. 2020. Dampak Covid-19 Terhadap Perekonomian Indonesia, EduPsyCouns Journal. 2 (1):151,1-5. https://doi.org/10.1186/s13104-02005044-y 
Pepinsky, T. B., \& Wihardja, M. M. 2011. Decentralization and Economic Performance in Indonesia, Journal of East Asian Studies, 11(3), 337-371. https://doi.org/10.1017/S15982408000 $\underline{07372}$

Sanusi, Anwar. 2016. Metodologi Penelitian Bisnis, Jakarta: Salemba Empat. hal. 32

Sihaloho, Estro Darianto. 2020. Dampak Covid-19 terhadap Perekonomian Indonesia, Researchgate; Departemen Ilmu Ekonomi Universitas Padjajaran.

Mardiyah, R.A., Nunung Nurwati. 2020. Dampak Pandemi Covid-19 Terhadap Peningkatan Angka Pengangguran di Indonesia. Jurnal Ilmu Sosial.

Hidayat, Khomarul. 2020. Pemerintah akan maksimalkan anggaran PEN di kuartal III. Diunduh 6 Juli 2021, http://nasional.kontan.co.id/news/peme rintah-akan-maksimalkan-anggaranpen-di-kuartal-iii-2020

Tim detikcom. 2020. Kapan Sebenarnya Corona Pertama Kali Masuk RI?.Detiknews, Diunduh dari https://news.detik.com/berita/d4991485/kapan-sebenarnya-coronapertama-kali-masuk-ri

Permatasari, Desi. 2021. Kebijakan Covid-19 dari PSBB hingga PPKM level 4. Diunduh dari https://kompaspedia.kompas.id/baca/inf ografik/kronologi/kebijakan-covid-19dari-psbb-hingga-ppkm-empat-level

Biro KLI. 2021. Realisasi Penanganan Covid-19 dan PEN hingga Agustus Capai 21,8\%. Diunduh dari https://www.kemenkeu.go.id/publikasi/ berita/realisasi-penanganan-covid-19dan-pen-hingga-agustus-capai-21-8/

Purwanto, Antonius. 2021. Ekonomi Indonesia pada Masa Pandemi Covid19: Potret dan Strategi Pemuihan 20202021. Diunduh dari https://kompaspedia.kompas.id/baca/pa paran-topik/ekonomi-indonesia-pada- masa-pandemi-covid-19-potret-danstrategi-pemulihan-2020-2021

Ferry. 2021. Menkeu Jelaskan Jaring Pengaman Sosial dalam Penanganan Covid-19 pada IMF. Diunduh dari https://www.kemenkeu.go.id/publikasi/ berita/menkeu-jelaskan-jaringpengaman-sosial-dalam-penanganancovid-19-pada-imf/

Webinar Semeru Institute. 2021. Analisis Dampak Sosial dan Ekonomi Pandemi terhadap Rumah Tangga di Indonesia. diunduh dari https://smeru.or.id/id/content/analisisdampak-sosial-dan-ekonomi-pandemiterhadap-rumah-tangga-di-indonesia

Perppu Nomor 1 Tahun 2020 tentang Kebijakan Keuangan Negara dan Stabilitas Sistem Keuangan untuk Penanganan Pandemi Covid-19 dalam Rangka Menghadapi Ancaman yang membahayakan Perekoniman Nasional atau stabilitas Sistem Keuangan.

Undang-Undang Nomor 2 Tahun 2020 tentang Penetapan Peraturan Pemerintah Pengganti Undang-Undang Nomor 1 Tahun2020

Peraturan Presiden Nomor 54 Tahun 2020 tentang Perubahan Postur dan Rincian Anggaran Pendapatan dan Belanja Negara Tahun Anggaran 2020

Peraturan Presiden Nomor 72 Tahun 2020 tentang Perubahan Postur dan Rincian APBN 2020

Peraturan Pemerintah Nomor 23 Tahun 2020 tentang Pemulihan Ekonomi Nasional dalam Rangka Mendukung Kebijakan Keuangan Negara untuk Penanganan Pandemi Covid-19 dan/atau Menghadapi Ancaman yang Membahayakan Perekonomian Nasional dan/atau Stabilitas Sistem Keuangan serta Penyelamatan Ekonomi Nasional.

Peraturan Presiden Nomor 82 Tahun 2020 tentang Komite Penanganan Covid19. 